\title{
Haploinsufficiency of Casitas B-Lineage Lymphoma Augments the Progression of Colon Cancer in the Background of Adenomatous Polyposis Coli Inactivation
}

Sean Richards, ${ }^{*}$ Joshua Walker, ${ }^{*}$ Masako Nakanishi, ${ }^{\dagger}$ Mostafa Belghasem, ${ }^{\ddagger}$ Chimera Lyle, ${ }^{*}$ Nkiruka Arinze, ${ }^{\S}$ Marc A. Napoleon, ${ }^{*}$ Jonathan D. Ravid, ${ }^{\llbracket}$ Nicholas Crossland, ${ }^{\ddagger}$ Qing Zhao, ${ }^{\ddagger}$ Daniel Rosenberg, ${ }^{\dagger}$ Nader Rahimi, ${ }^{\ddagger}$ and Vipul C. Chitalia* $\|_{* *}$

From the Department of Medicine, ${ }^{*}$ Boston University School of Medicine, Boston, Massachusetts; the Center for Molecular Oncology, ${ }^{\dagger}$ University of Connecticut Health Center, Farmington, Connecticut; the Departments of Pathology and Laboratory Medicine ${ }^{\ddagger}$ and Surgery, ${ }^{\S}$ Boston University School of Medicine, Boston, Massachusetts; the School of Medicine, "Boston University, Boston, Massachusetts; the Veterans Affairs Boston Healthcare System, "Boston, Massachusetts; and Global Co-Creation Labs, ** Institute of Medical Engineering and Sciences, Massachusetts Institute of Technology, Cambridge, Massachusetts

Accepted for publication October 23, 2019.

Address correspondence to Vipul C. Chitalia, M.D., Ph.D., Department of Medicine, Boston University School of Medicine, 650 Albany St., Floor 5, Boston MA, 02118. E-mail: vichital@ bu.edu.

\begin{abstract}
Casitas B-lineage lymphoma ( $\mathrm{c}-\mathrm{Cbl})$ is a recently identified ubiquitin ligase of nuclear $\beta$-catenin and a suppressor of colorectal cancer (CRC) growth in cell culture and mouse tumor xenografts. We hypothesized that reduction in $\mathrm{c}-\mathrm{Cbl}$ in colonic epithelium is likely to increase the levels of nuclear $\beta$-catenin in the intestinal crypt, augmenting CRC tumorigenesis in an adenomatous polyposis coli $\left(\mathrm{APC}^{\Delta 14 /+}\right.$ ) mouse model. Haploinsufficient $\mathrm{c}-\mathrm{Cbl}$ mice $\left(\mathrm{APC}^{\Delta 14 /+} \mathrm{c}^{-\mathrm{Cbl}^{+/-}}\right.$) displayed a significant (threefold) increase in atypical hyperplasia and adenocarcinomas in the small and large intestines; however, no differences were noted in the adenoma frequency. In contrast to the APC ${ }^{\Delta 14 /+}{ }^{c-C} \mathrm{Cbl}^{+/+}$mice, APC ${ }^{\Delta 14 /+}$ $\mathrm{c}^{-\mathrm{Cbl}^{+/-}}$crypts showed nuclear $\beta$-catenin throughout the length of the crypts and up-regulation of Axin2, a canonical Wnt target gene, and SRY-box transcription factor 9, a marker of intestinal stem cells. In contrast, haploinsufficiency of ${\mathrm{c}-\mathrm{Cbl}^{+/}-}^{-}$alone was insufficient to induce tumorigenesis regardless of an increase in the number of intestinal epithelial cells with nuclear $\beta$-catenin and SRY-box transcription factor 9 in $\mathrm{APC}^{+/+} \mathrm{c}_{-} \mathrm{Cbl}^{+/-}$mice. This study demonstrates that haploinsufficiency of $\mathrm{c}-\mathrm{Cbl}$ results in Wnt hyperactivation in intestinal crypts and accelerates CRC progression to adenocarcinoma in the milieu of APC ${ }^{\triangle 14 /+}$, a phenomenon not found with wild-type APC. While emphasizing the role of APC as a gatekeeper in CRC, this study also demonstrates that combined partial loss of $\mathrm{c}-\mathrm{Cbl}$ and inactivation of APC significantly contribute to CRC tumorigenesis. (Am J Pathol 2020, 190: 602-613; https:// doi.org/10.1016/j.ajpath.2019.10.024)
\end{abstract}

Colorectal cancer (CRC) is the third most commonly diagnosed malignancy in the world. Although aggressive surveillance programs and targeted therapies have substantially improved the management of CRC, it still constitutes the fourth leading cause of cancer-related deaths ${ }^{1}$ and global burden is expected to increase to $>2.2$ million new cases and 1.1 million deaths by $2030 .{ }^{1,2}$ Most CRC-related deaths are secondary to progression of the disease and metastases. Consequently, it is imperative to understand the factors influencing the initiation and progression of CRC.
The Wnt/ $\beta$-catenin pathway plays a seminal role in the initiation and progression of tumors in a vast majority of sporadic CRC cases. ${ }^{3,4}$ Loss-of-function mutations of

Supported in part by National Cancer Institute grants R01CA175382 (V.C.C.), R21CA191970 (N.R.), and R21CA193958 (N.R.); NIH grant R01 HL132325 (V.C.C.); Evans Faculty Merit award (V.C.C.); National Cancer Institute T32 training in renal biology grant T32 DK007053-44 (C.L.); National Cancer Institute T32 training grant in cardiovascular biology grant T32 HL007224-40 (J.W.); and National Cancer Institute T32 immunobiology of trauma grant 2T32GM086308-06A1 (N.A.).

Disclosures: None declared. 
tumor suppressor adenomatous polyposis coli $(A P C)$ drives CRC through $\beta$-catenin, the central mediator of Wnt activity and a potent oncoprotein. ${ }^{5,6}$ In the proposed model of Wnt signaling, wild-type APC binds to $\beta$-catenin in the destruction complex within the cytosol. This binding induces $\beta$-catenin to undergo serine and threonine phosphorylation that stamps it for degradation. $\beta$-Catenin is predominantly regulated by ubiquitination and proteasomal degradation by a set of E3 ubiquitin ligases [namely, beta transducin repeat containing protein $(\beta-\operatorname{TrCP})$ and Jade-1]. ${ }^{7-9}$ Inactivating mutations in $A P C$ allow the escape of $\beta$-catenin from phosphorylation, its nuclear translocation, and aberrant and relentless activation of proproliferative and pro-oncogenic Wnt target genes in the nucleus, driving colorectal tumorigenesis.

Recent studies have shown that Casitas B-lineage lymphoma (c-Cbl) uniquely targets nuclear $\beta$-catenin for degradation. ${ }^{8,10,11} \mathrm{c}-\mathrm{Cbl}$ is a really interesting new gene (RING)-finger containing E3 ligase that targets $\beta$-catenin and several receptor and nonreceptor tyrosine kinases. ${ }^{12} \mathrm{c}$ $\mathrm{Cbl}$ interacts with the central armadillo region of $\beta$-catenin, irrespective of its phosphorylation status at the $\mathrm{N}$ terminus. This site of interaction on $\beta$-catenin allows c-Cbl to ubiquitinate different species of $\beta$-catenin (namely, the wild-type and mutant $\beta$-catenin, which lacks serine phosphorylation residues, or active $\beta$-catenin in the setting of $A P C$ mutation). ${ }^{10}$ Recent studies have shown that in CRC cells, c-Cbl ubiquitinates nuclear $\beta$-catenin and targets it for proteasomal degradation. ${ }^{8}$ In human $\mathrm{CRC}$, the c-Cbl levels inversely correlate with nuclear $\beta$-catenin and overall survival of patients with stage IV CRC. ${ }^{10}$ Xenografts in athymic mice injected with $C B L$ silenced cells showed significantly higher nuclear $\beta$-catenin and rate of tumor growth. ${ }^{10}$

Although previous work has demonstrated $\mathrm{c}-\mathrm{Cbl}$ as a suppressor of mouse xenograft, ${ }^{10}$ there are no studies examining its role in the model of spontaneous colon cancer tumorigenesis. We further probed the role of c-Cbl in CRC tumorigenesis using a mouse model of CRC. From several models of $\mathrm{CRC},{ }^{13} \mathrm{APC}^{\Delta 14 /+}$ mice harboring a truncated form of $A P C$ at codon 580, which deletes the putative binding sites of $\beta$-catenin (15- and 20-amino acid repeats downstream of the armadillo region), were chosen. ${ }^{14}$ This APC mutation will allow $\beta$-catenin to escape phosphorylation and degradation by E3 ligases other than c-Cbl, and is an appropriate model to validate the role of c-Cbl. Moreover, $\mathrm{APC}^{\Delta 14 /+}$ mice bear several molecular, histopathologic, and clinical features similar to human CRC. ${ }^{14}$ The $\mathrm{Apc}^{\mathrm{Min}}$ model develops cancers principally in the small intestine. ${ }^{13}$ In addition to the tumors in small intestines, $\mathrm{APC}^{\Delta 14 /+}$ mice develop tumors in distal colon and rectum, which is similar to human CRC. Unlike the Apc ${ }^{\mathrm{Min}}$ model, $\mathrm{APC}^{\Delta 14 /+}$ mice showed early lesions and progression of tumors from high-grade dysplasia to in situ adenocarcinomas similar to human CRC. Taken together, the similarities to human disease in terms of lesion distribution and the unique deletion of the critical armadillo domain provided strong rationale for selecting $\mathrm{APC}^{\Delta 14 /+}$ mice over $\mathrm{Apc}^{\mathrm{Min}}$ as the model for the current study. Although a knockout mouse model is traditionally preferred for such purpose, our attempts to generate a compound heterozygote $\mathrm{APC}^{\Delta 14 /+} \mathrm{c}$ $\mathrm{Cbl}^{-1-}$ mouse strain failed because of hypofertility in male offspring given high expression of c-Cbl in the Sertoli cells and apoptosis of sperm cells with reduced c-Cbl activity. ${ }^{15}$ However, haploinsufficiency of c-Cbl was sufficient to reveal differences in the intestinal proliferative and neoplastic phenotypes in mice.

\section{Materials and Methods}

\section{Generation of APC ${ }^{\Delta 14 /+}$ and c-Cbl Double- Heterozygote Mice}

All mice used in this study were bred and maintained at Boston University Medical Center (Boston, MA) after approval from the Institutional Animal Care and Use Committee (AN-15449). ${\mathrm{c}-\mathrm{Cbl}^{+/}}^{+-}$male and female mice on C57/ BL6J background were obtained from Dr. Jeffrey Chiang (National Cancer Institute, Bethesda, MD). ${ }^{16}$ Because of ectoparasite infection of these animals, according to the policy of Institutional Animal Care and Use Committee, a clean line of ${\mathrm{c}-\mathrm{Cbl}^{+-}}^{+-}$was rederived using a standard in vitro fertility protocol. Briefly, male mice were euthanized, and sperm was extracted and preincubated in a medium with 0.25 $\mathrm{mmol} / \mathrm{L}$ glutathione/Cook medium. After confirming the sperm recovery, as determined by $100 \%$ motility, an in vitro fertility protocol was performed. Donor eggs were obtained from C57BL/6J female mice (Jackson Laboratory, Bar Harbor, ME; catalog number $000664 \mathrm{~B} 6 / \mathrm{J})$, which is the same background as the original ${\mathrm{c}-\mathrm{Cbl}^{-/-}}^{-1}$ mice. Fifteen 5week-old females with moderately expanded or nearly expanded ampullas were used, and 235 oocytes were harvested from 15 donors. A total of 156 zygotes were confirmed using polar bodies with $66 \%$ fertilization rate. All the embryos were distributed evenly among five plugged recipient mothers with nearly 16 embryos per oviduct. Subsequent offspring were genotyped using a pair of primers for the wild-type allele [CBL wild type, 5'-GACGATAGTCCCGTGGAAGAGCTTTCGACA-3' (forward) and 5'-CCTAAGTGGTAGGATTATAATTGCAAGCCACCA-3' (reverse)] and a set of primers for the knockout allele [CBL knockout, $5^{\prime}$-TCCCCTCCCCTTCCCATGTTTTTAATAGACTC-3' (forward)] and locus of $\mathrm{x}$ over P1 [LOX-P; 5'-TGGCTGGACGTAAACTCCTCTTCAGAACCTAATAAC-3' (reverse)]. $\mathrm{APC}^{\Delta 14 /+}$ male and female mice were obtained from Dr. Daniel Rosenberg (University of Connecticut Health Center, Farmington, CT). Offspring of the several breeding pairs were genotyped using PCR and a set of primers for the knockout allele Apc.Int13S (forward: 5'-CTAGTACTTTTCAGACGTCATG-3') and Apc.Int14a (reverse: 5'-CAATATAATGAGCTCTGGGCC- $3^{\prime}$ ).

Once both $\mathrm{c}-\mathrm{Cbl}^{+/-}$and $\mathrm{APC}^{\Delta 14 /+}$ colonies were established, breeding pairs were set up between these two strains 
to generate double-heterozygote animals. $\mathrm{APC}^{\Delta 14 /+}$ mice served as controls. Offspring of these pairs were genotyped using both $\mathrm{c}-\mathrm{Cbl}$ and APC primers to confirm double deficiency.

\section{Intestine Harvest and Quantification of Polyp}

Mice were euthanized, and the colon and small intestine were harvested. A gavage needle was used to flush the colon and small intestine with $40 \mathrm{~mL}$ of ice-cold phosphate-buffered saline. Organs were then stretched across filter paper, opened longitudinally, and fixed in $10 \%$ formalin overnight at $4^{\circ} \mathrm{C}$. After fixation, organs were rehydrated in successive baths of $70 \%$ ethanol and phosphate-buffered saline. The tissue was Swiss rolled, with the distal end of the intestine closest to the center of the coil, and the proximal end at the outside.

\section{Histology and Immunohistochemistry}

Swiss rolled intestines were paraffin embedded and divided into sections ( $5 \mu \mathrm{m}$ thick) for histologic examination. Three sections from different segments of the block were stained with hematoxylin and eosin and graded by a veterinary pathologist (N.C.) and a surgical pathologist (M.B. or Q.Z.) in a blinded manner for detection of atypical hyperplasia, adenoma, or adenocarcinoma. Additional sections were used for immunohistochemistry or immunofluorescence staining.

\section{Antibody}

A set of prevalidated antibodies was used, as shown in Table 1. c-Cbl antibody used (Santa Cruz Biotechnology, Dallas, TX; catalog number sc-1651) detects a putative epitope at amino acids 892 to 906 at the $\mathrm{C}$ terminus of human $\mathrm{Cbl}$, and it recognizes mouse and human $\mathrm{c}-\mathrm{Cbl}$ by Western blot analysis and immunohistochemistry. Although both c-Cbl and casitas B lineage lymphoma B (Cbl-b) share homology in several domains, the C-terminal region recognized by the antibody ( 892 to 906) only shares four amino acids (Supplemental Figure S1A). Therefore, it is unlikely that this particular antibody cross-reacts with Cbl-b. To ascertain this deduction, HEK 293T cells were transfected with human c-Cbl and Cbl-b constructs, and cell lysates were probed separately with prevalidated c-Cbl (Santa Cruz Biotechnology; catalog number sc-1651) and Cbl-b (Cell Signaling, Cambridge, MA; catalog number 9498) antibodies. Actin served as a loading control. Western blot results showed that c-Cbl antibody does not cross-react with Cbl-b, and vice versa (Supplemental Figure S1B).

\section{Histopathologic Analysis}

Hematoxylin and eosin-stained tissue sections were examined by a board-certified veterinary pathologist (N.C.) blinded to genotype. Some of the slides were also evaluated by a board-certified surgical pathologist (Q.Z.) specializing in abdominal cancers. Three sections taken at different depths of the block were examined for each animal, each containing three Swiss roll tissue sections (proximal small intestines, distal small intestines, and colon). Lesions were classified as atypical hyperplasia, adenoma, or adenocarcinoma on the basis of preexisting criteria described in the International Harmonization of Nomenclature and Diagnostic Criteria for Lesions in Rats and Mice project for nonproliferative and proliferative lesions of the gastrointestinal tract, pancreas, and salivary glands of the rat and mouse. ${ }^{17}$

\section{RT-PCR of CBL mRNA}

Organs of c-Cbl ${ }^{+/+}$and $\mathrm{c}-\mathrm{Cbl}^{+/-}$mice were harvested and stored at $-80^{\circ} \mathrm{C}$ until RNA extraction was performed. RNA was extracted using the RNeasy Mini Kit from Qiagen (Hilden, Germany; 74104). Tissue $(15 \mu \mathrm{g})$ was homogenized in $350 \mu \mathrm{L}$ of RLT buffer, and processed according to the kit's protocol. Concentration and purity of the RNA were measured, and cDNA was generated using an RT-PCR kit from Applied Biosystems (Foster City, CA; 4368814). cCbl mRNA was quantified by quantitative real-time PCR using the animals' cDNA and TaqMan gene expression probes from Thermo Fisher (Waltham, MA; 4331182).

\section{Statistical Analysis}

Summary statistics are presented using the mean, median, SD, and SEM. Differences in the pathologic features between the two groups were analyzed using contingency table and Fisher exact test. Two-tailed $P<0.05$ was considered statistically significant.

\section{Results}

The expression of c-Cbl was first examined in colonic epithelium in wild-type C57BL/6J mice. Although c-Cbl was expressed in the epithelial cells of both small and large intestines, its expression was higher in the upper part of

Table 1 Antibodies and Their Dilutions Used for the Study

\begin{tabular}{llll}
\hline Antibody & Vendor & Catalog no. & Dilution \\
\hline c-Cbl & Santa Cruz Biotechnology (Dallas, TX) & sc-1651 & $1: 100$ \\
Anti- $\beta$-catenin & BD Bioscience (Billerica, MA) & 610,154 & $1: 100$ \\
SRY-box transcription factor 9 & Millipore (Burlington, MA) & ABE571 \\
Axin2 & Abcam (Cambridge, UK) & ab32179 & $1: 100$ \\
\hline
\end{tabular}




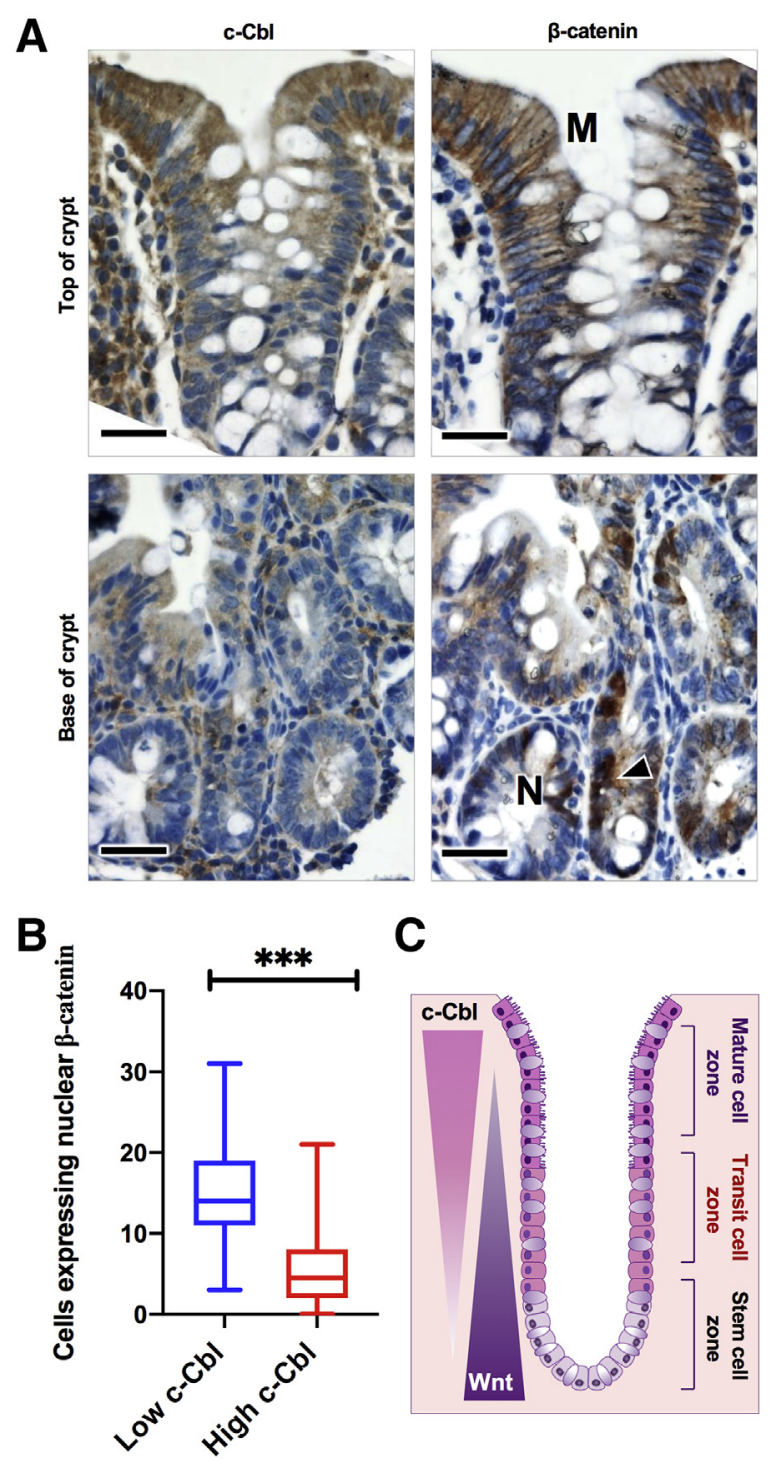

Figure 1 Inverse relationship of c-Cbl expression and nuclear $\beta$-catenin in normal mouse colonic epithelial cells. A: Consecutive sections of intestine from 10- to 12-week-old wild-type mice were stained with $\mathrm{c}$ - $\mathrm{Cbl}$ and $\beta$ catenin antibodies and counterstained with hematoxylin. Representative images of a colonic crypt are shown. The top of the crypt shows cells with membrane (M) and cytosolic $\beta$-catenin, and the bottom of the crypt has cells with nuclear $(\mathrm{N}) \beta$-catenin (arrowhead). B: Intestines from five wild-type mice were stained with $\mathrm{c}-\mathrm{Cbl}$ and $\beta$-catenin antibodies and counterstained with hematoxylin. Ten randomly selected colon crypts were examined by two surgical pathologists in a blinded manner (M.B and Q.Z.). The expression of C$\mathrm{Cbl}$ was recorded as low and high, and cells with nuclear $\beta$-catenin were counted per crypt. $t$-test was applied to compare the number of cells expressing nuclear $\beta$-catenin. C: The structure of a normal colonic crypt with the base of the crypt harboring proliferating cells with higher Wnt activity. The top of the colon crypts harbors differentiated cells with the lower Wnt activity. A gradient in c-Cbl expression was noted along the crypt-villus axis, which was inverse to that of the Wnt activity, as reflected by the presence of nuclear $\beta$-catenin. Error bars indicate SEM (B). ${ }^{* *} P<0.001$. Scale bars $=25 \mu \mathrm{m}(\mathbf{A})$.

colonic crypts compared with the base of the crypt (Figure 1A). Consistent with previous reports, ${ }^{18}$ the upper part of the crypt showed membrane and cytosolic $\beta$-catenin, but no nuclear $\beta$-catenin, whereas some of the cells in the base of the crypts were positive for nuclear $\beta$-catenin (Figure 1A). The initial assessment showed a potential inverse relationship between the expression of $\mathrm{c}-\mathrm{Cbl}$ and nuclear $\beta$-catenin in the intestinal epithelial cells. To objectively demonstrate this relationship, c-Cbl-expressing cells in the crypt and the number of cells positive for nuclear $\beta$-catenin were examined by a surgical pathologist (M.B.) blinded to the specimens. Expression of $\mathrm{c}-\mathrm{Cbl}$ was graded semiquantitatively (low and high) in each cell, and the localization of $\beta$-catenin was determined. The number of cells positive for nuclear $\beta$-catenin was normalized to the number of cells in a crypt. A greater number of colonic cells with lower expression of $\mathrm{c}$-Cbl showed nuclear $\beta$-catenin $(14+6.8$ cells/crypt $)$ compared with the ones with higher expression of c-Cbl $(5.2+4.3$ cells/crypt; $P<0.001)$. These results suggested an inverse relationship between $\mathrm{c}-\mathrm{Cbl}$ and nuclear $\beta$-catenin (Figure 1B).

These results suggested that cells with lower c-Cbl expression had more nuclear $\beta$-catenin, supporting an inverse relationship between c-Cbl and nuclear $\beta$-catenin (Figure 1B).

The crypt typically consists of a proliferative compartment at the base in both the small intestine and the colon, as well as a differentiated, functional compartment, consisting of the villus in the small intestine and the luminal surface in the colon. ${ }^{18}$ Studies have shown that multipotent stem cells, located near the base of the crypts, generate new cells, which migrate to the villus while differentiating into enterocyte, goblet, and enteroendocrine cells. ${ }^{19}$ The base of the crypt is known to harbor cells positive for nuclear $\beta$-catenin, driving higher Wnt activity. ${ }^{20-23}$ As the colonic epithelial cells move up along the villus axis, nuclear $\beta$-catenin is down-regulated, and Wnt activity is switched off, inducing cell cycle arrest and differentiation ${ }^{20-23}$ (Figure 1C). The apices of crypts characterized by more differentiated cells showed higher $\mathrm{c}-\mathrm{Cbl}$ expression and a significantly lower number of cells with nuclear $\beta$-catenin. We therefore posited that the reduction in $\mathrm{c}-\mathrm{Cbl}$ in the colonic epithelium is likely to increase an aberrant expression of nuclear $\beta$ catenin throughout the crypt.

This hypothesis was examined in $\mathrm{APC}^{\Delta 14 /+}$ mice that show spontaneous tumorigenesis in their small and large intestines. ${\mathrm{c}-\mathrm{Cbl}^{+/-}}^{+/}$mice on $\mathrm{C} 57 \mathrm{BL} / 6$ background were bred with $\mathrm{APC}^{\Delta 14 /+}$ mice (on the same background) to generate a compound heterozygote $\mathrm{APC}^{\Delta 14 /+}{\mathrm{c}-\mathrm{Cbl}^{+/-}}^{+/}$ mouse strain. Mice were genotyped to determine the presence of $\mathrm{APC}^{\Delta 14 /+}$ and $\mathrm{c}^{-\mathrm{Cbl}^{+/-}}$alleles (Figure 2A). Reduction in c-Cbl at both mRNA and protein levels was confirmed in these mice in various tissues. c-Cbl is highly expressed in the testes ${ }^{15}$ and hematological cells in the spleen. ${ }^{24} \mathrm{c}$-Cbl mRNA extracted from the spleen was

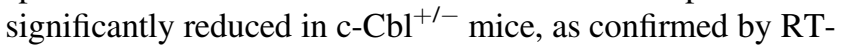
PCR (Figure 2B). As expected, lysates from the testes showed close to $50 \%$ reduction in $\mathrm{c}-\mathrm{Cbl}$ protein in $\mathrm{c}-\mathrm{Cbl}^{+/-}$ mice (Figure 2C). The colons of mice sacrificed at 12 weeks of age were further examined using immunohistochemistry. c-Cbl expression was substantially reduced in the colonic 
A

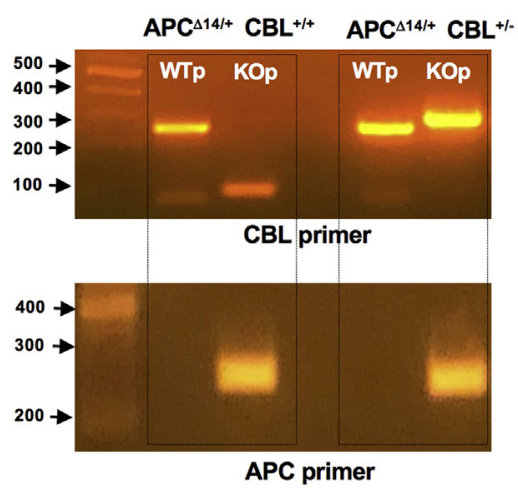

B
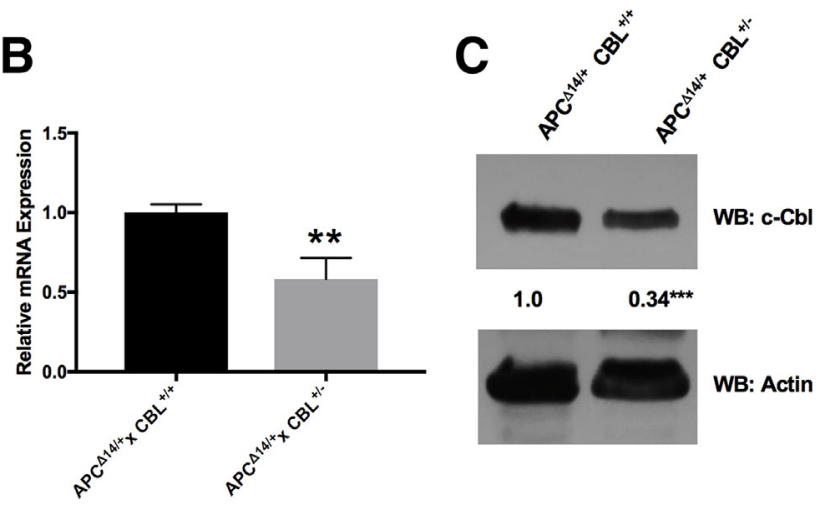

D

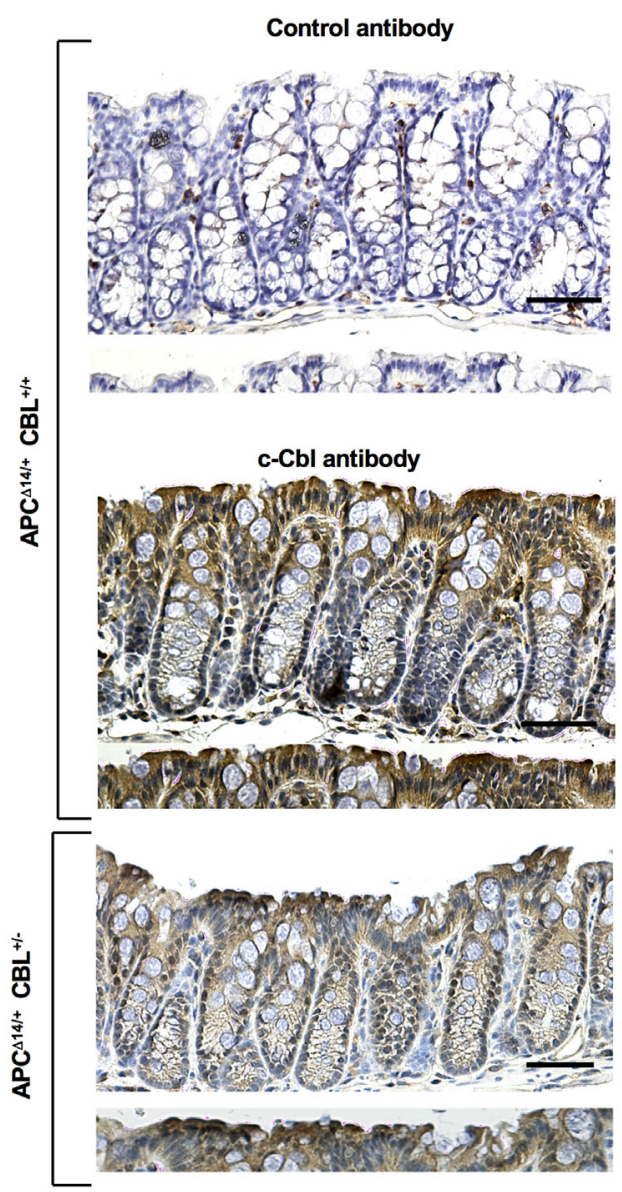

epithelium, especially in the cells at the apices of the crypts (Figure 2D).

Mice were typically sacrificed at three different ages: $\leq 10$ to 12 weeks, 12 to 16 weeks, and $\geq 16$ weeks of age, for a maximum duration of 24 weeks. The entirety of the intestine tract from these mice was examined using a Swiss roll technique, followed by a detailed histopathologic analysis $^{25,26}$ (Table 2). Examination of hematoxylin and eosin-stained sections revealed atypical hyperplasia, adenomas, and adenocarcinoma phenotypes in both small intestines and the colon (Figure 3). There was a higher incidence of atypical hyperplasia in both proximal and distal small intestines of c-Cbl-deficient mice. After 16 weeks of age, only $62.5 \%$ of $\mathrm{APC}^{\Delta 14 /+}{\mathrm{c}-\mathrm{Cbl}^{+/+}}^{+1}$ mice showed evidence of atypical hyperplasia in the proximal small intestine $(n=8)$, whereas all $\mathrm{APC}^{\Delta 14 /+}{\mathrm{c}-\mathrm{Cbl}^{+/-}}$mice $(n=8)$ showed evidence of atypical hyperplasia in that region $(P=0.02)$. Similarly, $66 \%$ of $\mathrm{APC}^{\Delta 14 /+}{\mathrm{c}-\mathrm{Cbl}^{+/+}}^{\text {mice }}$ showed evidence of atypical hyperplasia in the distal small intestines, whereas all $\mathrm{APC}^{\Delta 14 /+}{\mathrm{c}-\mathrm{Cbl}^{+/-}}^{+/ c e}$ showed evidence of atypical hyperplasia in that region $(P=0.05)$. This atypical hyperplasia was characterized by focal proliferation of intestinal epithelial cells and was noted mostly at the surface of the apical villus. Some of the atypical hyperplasia was seen in the Brunner gland. Adenomas were mostly tubular or tubulopapillary in morphology. Although no significant differences in adenocarcinomas were noted in the proximal small intestines between the two groups, $14 \%$ of $\mathrm{APC}^{\Delta 14 /+}{\mathrm{c}-\mathrm{Cbl}^{+/+}}$versus $55 \%$ of $\mathrm{APC}^{\Delta 14 /+}{\mathrm{c}-\mathrm{Cbl}^{+/-}}^{+/ 2}$ mice displayed evidence of adenocarcinomas in the distal small intestines $(P<0.001)$ (Figure 3$)$.

Interesting differences were noted in the colon of the two groups at the earlier time points. For example, between

\footnotetext{
Figure 2 Generation of a compound heterozygote $\mathrm{APC}^{\mathrm{114/+}} \mathrm{c}-\mathrm{Cbl}^{+/-}$ mouse strain. A: $\mathrm{APC}^{\Delta 14 /+}$ mice were cross-bred with $\mathrm{c}-\mathrm{Cbl}^{+/-}$mice to generate a compound heterozygote mouse strain. Each mouse was genotyped for c-Cbl (top panel) and $\mathrm{APC}^{\Delta 14 /+}$ (bottom panel). c-Cbl was determined by the presence of either one product or two products, when using a distinct set of primers for the wild-type (WTp) and knockout (KOp) primers (Materials and Methods). APC ${ }^{\Delta 14 /+}$ was determined by the presence of a PCR product of approximately $265 \mathrm{bp}$. Representative image of genotyping performed for all the mice used in the current study. B: RT-PCR was used to confirm reduction in $C B L \mathrm{mRNA}$. Average of three independent experiment is shown. $t$-test was used. C: The testes of mice were harvested, and the lysates were probed for $\mathrm{c}-\mathrm{Cbl}$ and actin, which served as a loading control. ImageJ software version 2.0.0-rc-9 (NIH, Bethesda, MD; https:// imagej.nih.gov/ij) was used to normalize the $\mathrm{c}-\mathrm{Cbl}$ band and is depicted below the $\mathrm{c}-\mathrm{Cbl}$ immunoblot. Representative immunoblots from three experiments are shown. D: Colonic tissue of mice was stained for c-Cbl and counterstained with hematoxylin. Representative images from 25 $\mathrm{APC}^{\Delta 14 /+}{\mathrm{c}-\mathrm{Cbl}^{+/+}}^{+/ c e}$ and $\mathrm{APC}^{\Delta 14 /+}{\mathrm{c}-\mathrm{Cbl}^{+/-}}^{+}$mice are shown. Isotype control antibody serves as a negative control. The bottom part of each panel corresponds to the top of the epithelial layer of intestinal crypt shown in the top part of a panel. Error bars indicate SEM (B). ${ }^{* *} P<0$. $01,{ }^{* * *} P<0.001$ versus $\mathrm{APC}^{\Delta 14 /+}{\mathrm{C}-\mathrm{Cbl}^{+/+}}$. Scale bars $=25 \mu \mathrm{m}(\mathbf{D}$, top panels). Original magnification: $\times 100$ (D, top panels); $\times 200$ (D, bottom panels). WB, Western blot.
} 
Table 2 Percentage of Mice with the Intestinal Phenotype in Both the Groups

\begin{tabular}{|c|c|c|c|c|c|c|}
\hline \multirow[b]{2}{*}{ Variable } & \multicolumn{2}{|c|}{ Proximal small intestine } & \multicolumn{2}{|l|}{ Distal small intestine } & \multicolumn{2}{|l|}{ Colon } \\
\hline & $\overline{\mathrm{APC}^{\Delta 14 /+} \mathrm{c}-\mathrm{Cbl}^{+/+}}$ & 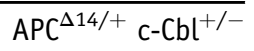 & $\overline{\mathrm{APC}^{\Delta 14 /+} \mathrm{c}-\mathrm{Cbl}^{+/+}}$ & 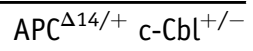 & $\overline{\mathrm{APC}^{\Delta 14 /+} \mathrm{c}-\mathrm{Cbl}^{+/+}}$ & $\mathrm{APC}^{\Delta 14 /+} \mathrm{c}_{-} \mathrm{Cbl}^{+/-}$ \\
\hline $\begin{array}{l}\text { Atypical } \\
\text { hyperplasia }\end{array}$ & $62.5^{*}$ & $100^{*}$ & $71^{*}$ & $100^{*}$ & 0 & 0 \\
\hline Adenoma & 85 & 88 & 85 & 88 & 11 & 11 \\
\hline Adenocarcinoma & 15 & 0 & $14^{*}$ & $45^{*}$ & $33^{* \dagger}$ & $55^{*}$ \\
\hline
\end{tabular}

All the data represent percentages of mice (aged $>16$ weeks) with the phenotype.

${ }^{*} P<0.05$.

${ }^{\dagger}$ Mice aged 12 to 16 weeks.

12 and 16 weeks, a higher proportion of $\mathrm{APC}^{\Delta 14 /+} \mathrm{c}-\mathrm{Cbl}^{+/-}$ mice $(25 \%)$ showed atypical hyperplasia in colon compared with no lesions in $\mathrm{APC}^{\Delta 14 /+}{\mathrm{c}-\mathrm{Cbl}^{+/+}}^{\Delta i c e}(P<0.001)$. Also, in the same period, $55 \%$ of $\mathrm{APC}^{\Delta 14 /+}{\mathrm{c}-\mathrm{Cbl}^{+/-}}^{\Delta i c e}$ showed adenocarcinoma compared with $33 \%$ in $\mathrm{APC}^{\Delta 14 /+}$

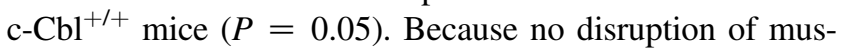
cularis mucosa was noted in most of those cases, the tumors were categorized as adenocarcinoma in situ. Adenocarcinomas showed poorly differentiated complex glandular structures, nuclear stratification, higher mitotic index, and increased number of aberrant, tortuous structures with cystic degeneration. However, no statistical differences in the pathologic features of adenocarcinomas were noted among

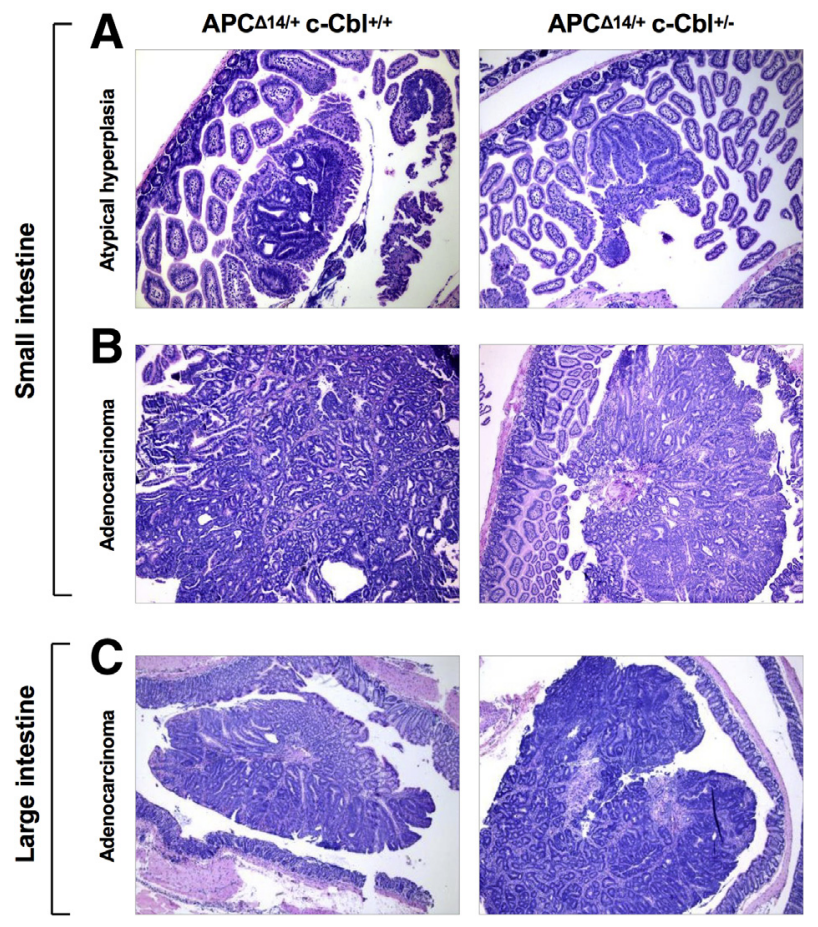

Figure 3 Adenoma and adenocarcinoma increase with reduction in c- $\mathrm{Cbl}$ activity. A: Hematoxylin and eosin (H\&E) staining of atypical hyperplasia in the proximal small intestine of $\mathrm{APC}^{\Delta 14 /+} \mathrm{C}_{-} \mathrm{Cbl}^{+/+}$and $\mathrm{APC}^{\Delta 14 /+} \mathrm{C}_{-}-\mathrm{Cbl}^{+/-}$ mice. Representative images from eight $\mathrm{APC}^{\Delta 14 /+}{ }_{\mathrm{C}-\mathrm{Cbl}^{+/+}}$and $\mathrm{APC}^{\Delta 14 /+}$

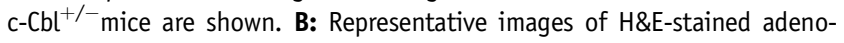
carcinoma in the distal small intestine of both the groups of mice are shown. C: Representative images of H\&E-stained adenocarcinoma in the colon of both the groups of mice are shown. Original magnification, $\times 40(\mathrm{~A}-\mathrm{C})$. both the groups. All the above data suggested that the $\mathrm{APC}^{\Delta 14 /+} \mathrm{c}-\mathrm{Cbl}^{+/-}$mice developed early lesions and progression to adenocarcinomas.

Because $c-C b l$ and nuclear $\beta$-catenin exhibit an inverse relationship in the colonic epithelium (Figure 1) and the reduction in $\mathrm{c}-\mathrm{Cbl}$ activity increased colonic tumors and their progression, we hypothesized that the reduction in $\mathrm{c}-\mathrm{Cbl}$ activity is likely to increase nuclear $\beta$-catenin throughout the colonic crypt. The above contention was examined in the normal colonic crypt between $\mathrm{APC}^{\Delta 14 /+}{\mathrm{c}-\mathrm{Cbl}^{+/-}}^{+/}$and $\mathrm{APC}^{\Delta 14 /+} \mathrm{c}-C b l^{+/+}$mice. As expected, $\mathrm{APC}^{\Delta 14 /+} \mathrm{c}-C b l^{+/+}$ mice showed nuclear $\beta$-catenin prominently at the base of the crypt, and $\beta$-catenin was seen primarily in the cytosol or membrane of intestinal cells at the apices of crypts. In contrast, c-Cbl deficiency was characterized by colonic epithelial cells with nuclear $\beta$-catenin throughout the entirety of crypt and at the top of the intestinal crypt (Figure 4, A and $\mathrm{B})$, as well as by increased nuclear expression at the base of the colonic crypt (Figure 4C). APC ${ }^{\Delta 14 /+}{\mathrm{c}-\mathrm{Cbl}^{+/-}}^{+1}$ crypts had threefold greater percentage of colonic epithelial cells with nuclear $\beta$-catenin $(67.5 \%+25.10 \%)$ compared with $\mathrm{APC}^{\Delta 14 /+} \mathrm{c}-C b l^{+/+}$mice $(22.14 \%+10.5 \% ; P<0.001)$ (Figure 4D). Taken together, these data suggested that partial loss of c-Cbl resulted in a significant increase in colonic epithelial cells showing nuclear $\beta$-catenin throughout the crypts, including the apices. The presence of nuclear $\beta$-catenin at the apices of intestinal crypt with the reduction in $\mathrm{c}-\mathrm{Cbl}$ is in stark contrast with the $\mathrm{APC}^{\Delta 14 /+}{\mathrm{c}-\mathrm{Cbl}^{+/+}}^{+1}$ mice, which showed no nuclear $\beta$-catenin in that above region (Figure 1B).

The presence of nuclear $\beta$-catenin along the crypt-villus axis suggests activation of Wnt signaling throughout the intestinal crypts of $\mathrm{APC}^{\Delta 14 /+}{\mathrm{c}-\mathrm{Cbl}^{+/-}}^{+2}$ mice. Wnt target genes are cell type specific. ${ }^{5,27}$ In colonic epithelium, AXIN2 is a well-established direct target of $\beta$-catenin. Axin 2 promoter contains eight T-cell factor/lymphoid enhancer factor consensus binding sites, which drive rapid induction of Axin2 mRNA and protein with Wnt activation. ${ }^{28}$ Therefore, Axin2 expression was examined in the two groups of mice using immunofluorescence staining and DAPI staining for the nuclei (Figure 5A). There was a greater number of colonic epithelial cells per crypt expressing Axin2 in $\mathrm{APC}^{\Delta 14 /+}$ ${\mathrm{c}-\mathrm{Cbl}^{+/-}}^{+/}$mice compared with $\mathrm{APC}^{\mathrm{\Delta 14/+}}{\mathrm{c}-\mathrm{Cbl}^{+/+}}^{+1}$ mice. Analysis of nuclear Axin2 in intestinal cells was performed 

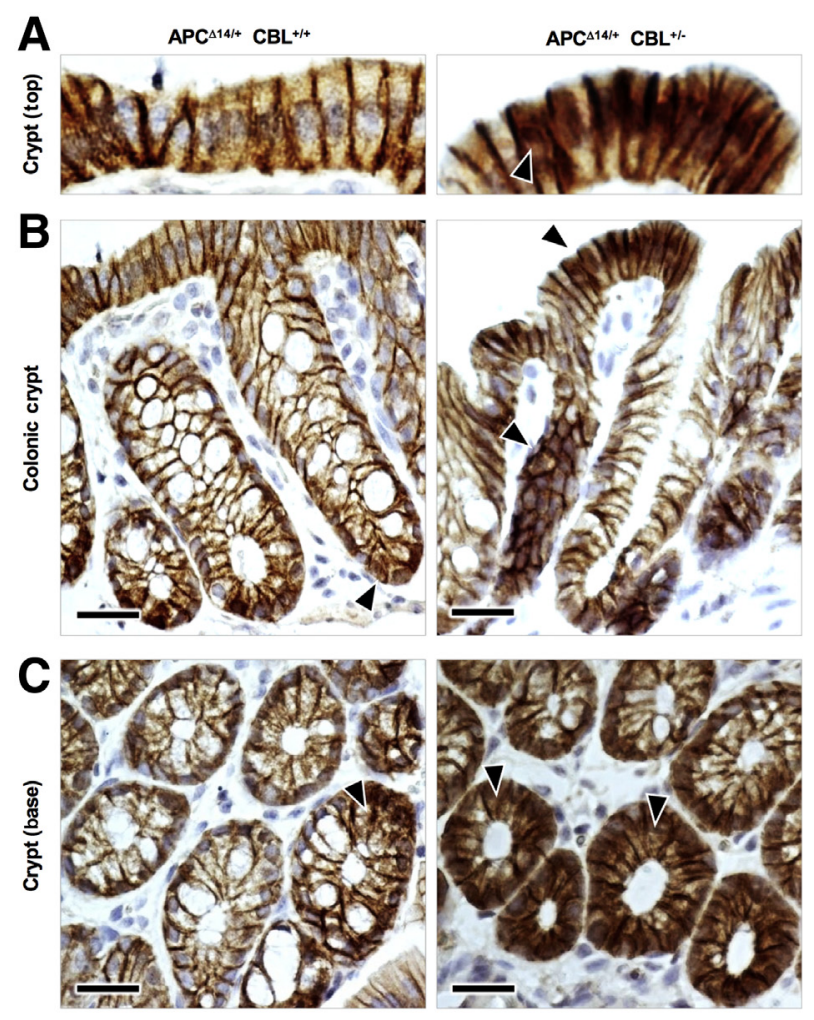

D

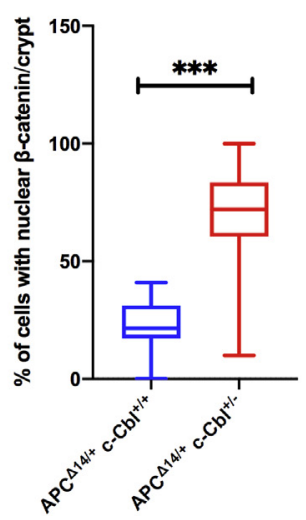

Figure 4 Aberrant expression of nuclear $\beta$-catenin throughout crypts with reduction in $\mathrm{c}-\mathrm{Cbl}$ activity. A: Immunohistochemistry of $\beta$-catenin-stained sections of colonic tissue from both the groups of mice is shown. Slides were counterstained with hematoxylin. Images were focused on cells at the top of colonic crypt. B and C: Representative images of the intestinal tissue (B) and the base of the crypt (C) from mice, as described in $\mathbf{A}$. D: Colonic epithelial cells at the base of crypts displaying nuclear $\beta$-catenin were counted and expressed as the percentage of total number of cells. Average of percentage cells positive for nuclear $\beta$-catenin from 10 randomly selected crypts from five mice from each group is shown. $t$-test was performed. Arrowheads indicate cells with nuclear $\beta$-catenin. Error bars indicate SD (D). $n=8$ per each group (B and $\mathbf{C}$ ). $* * * P<0.001$. Scale bars $=25 \mu \mathrm{m}(\mathbf{B}$ and $\mathbf{C})$. Original magnification: $\times 400$ (A); $\times 100$ (B and C).

on five random images from the intestinal sections of mice from both the groups and examined in a manner blinded (M.B.) to the identity of the samples. Cells positive for nuclear Axin2 were counted in proportion to the total number of cells within the crypt. A total of $20 \%+6.9 \%$ of intestinal cells of $\mathrm{APC}^{\Delta 14 /+} \mathrm{Cbl}^{+/+}$mice showed nuclear Axin2, whereas there was close to a twofold increase in cells bearing nuclear Axin2 in $\mathrm{APC}^{\Delta 14 /+} \mathrm{Cbl}^{+/-}$mice $(39.2 \%+13.52 \%$; $P=0.025$ ) (Figure 5, B and C). Although Axin2 is considered a negative regulator of Wnt signaling ${ }^{29}$ and its upregulation in colonic epithelial cells prevents relentless induction of oncogenic Wnt target genes, such as $M Y C,{ }^{30}$ Axin2 drives oncogenic activity through induction of Snaill, a key regulator of functional epithelial-mesenchymal transition program. ${ }^{31}$
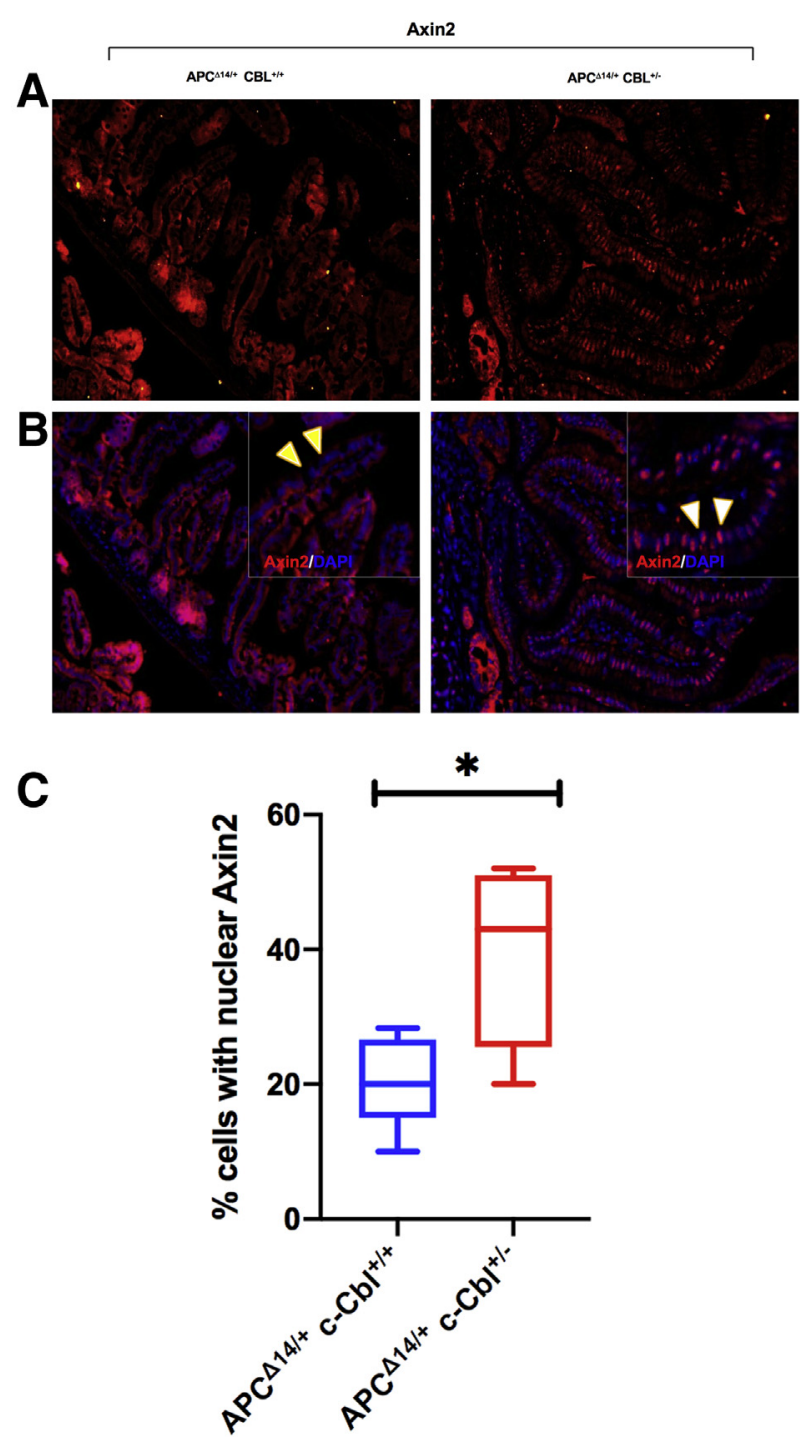

Figure 5 Increase in nuclear Axin2 in colonic epithelial cells of mice with decreased c-Cbl expression. A: Immunofluorescence images of colonic tissue stained for Axin2 from mice of both the groups. Representative images from $\mathrm{APC}^{\Delta 14 /+} \mathrm{C}_{-} \mathrm{Cbl}^{+/+}$and $\mathrm{APC}^{\Delta 14 /+}{\mathrm{C}-\mathrm{Cbl}^{+/-}}^{+}$mice are shown. B: Representative images of the intestinal tissue from mice, as described in $\mathbf{A}$, were stained with DAPI. Both the images were merged. Yellow arrowheads indicate the cytosol; white arrowheads, the nuclear Axin2. C: Colonic epithelial cells at the base of crypts displaying nuclear Axin2 were counted and expressed as the percentage of total number of cells. Average of percentage cells positive for nuclear Axin2 from five randomly selected images from five mice from each group is shown. Error bars indicate SD (C). $n=8$ mice per each group (B). ${ }^{*} P<0.05$ (t-test). Original magnification: $\times 200$ (A and B, main images); $\times 400$ (B, insets). 
SRY-box transcription factor 9 (SOX9) is a transcription factor that belongs to the superfamily of high-mobility group domain transcription factors. It is a well-established downstream gene of $\beta$-catenin, which contributes to the maintenance of progenitor phenotype. $^{32}$ SOX9 is normally expressed at the base of the colonic crypt, where it regulates Paneth cell differentiation. ${ }^{33}$ As a Wnt target gene, the expression of SOX9 was examined in $\mathrm{APC}^{\Delta 14 /+}{\mathrm{c}-\mathrm{Cbl}^{+/-}}^{+-}$ and $\mathrm{APC}^{\Delta 14 /+}{\mathrm{c}-\mathrm{Cbl}^{+/+}}^{+/}$mice. Examination of immunohistochemistry revealed significantly more SOX9 expression throughout the intestinal crypts of c-Cbl deficient mice (Figure 6A). Comparison of the number of intestinal cells with nuclear SOX9 was performed on 10 random images from the intestinal sections of two experimental groups examined in a manner blinded (M.B.) to the identity of the samples. A total of $1.7 \%+1.9 \%$ of intestinal cells/crypt of $\mathrm{APC}^{\Delta 14 /+} \mathrm{Cbl}^{+/+}$mice showed nuclear SOX9, whereas there was fivefold increase in cells bearing nuclear SOX9 in $\mathrm{APC}^{\Delta 14 /+} \mathrm{Cbl}^{+/-}$mice $(9.9 \%+5.42 \%$ cell/crypt; $P=0.003$ ) (Figure 6, B and C). Taken together, these results are consistent with the notion that partial c-Cbl deficiency in the setting of inactivation of $A P C$ results in increased nuclear $\beta$-catenin and expression of Wnt target genes in the colonic epithelium. Because Wnt activation drives the transformation of atypical hyperplasia to adenoma and plays a role in pathogenesis of adenocarcinoma, ${ }^{3,6}$ these findings are in line with the increased proportion of mice with colonic lesions with haploinsufficiency of c-Cbl (Figure 2).

Silencing of $\mathrm{c}-\mathrm{Cbl}$ in endothelial and epithelial cells increases nuclear $\beta$-catenin and Wnt activity and cell type-specific Wnt target genes. ${ }^{7,8,34}$ It was therefore examined if c-Cbl deficiency alone on wild-type APC background exhibits the evidence of hyperactive Wnt signaling in the intestinal epithelium and if it is associated with the development of adenomas or adenocarcinomas.

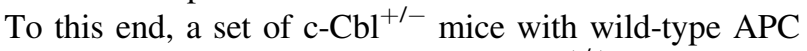

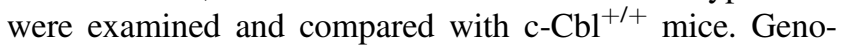
types of these mice were confirmed using DNA derived from tail clipping. Spleens of these mice accordingly showed close to $50 \%$ reduction in CBL mRNA and c-Cbl protein (Figure 7, A and B). c-Cbl ${ }^{+/-}$mice showed higher expression of $\mathrm{c}-\mathrm{Cbl}$ in the top of the crypts, which was reduced compared with $\mathrm{c}-\mathrm{Cbl}^{+/+}$mice (Figure $7 \mathrm{C}$ ).

These ${\mathrm{c}-\mathrm{Cbl}^{+/-}}^{+/}$mice were followed up for 4 months, and their intestines were processed as above. $\beta$-Catenin staining of the intestinal crypts showed a greater number of nuclear $\beta$-catenin-positive colonic epithelial cells at the base of the crypts in $\mathrm{c}-C b l^{+/-}$mice than in $\mathrm{c}-\mathrm{Cbl}^{+/+}$mice (Figure 8, A and B). In the same vein, SOX9 was found in the nuclei of colonic epithelial cells of $\mathrm{c}_{-} \mathrm{Cbl}^{+/-}$mice, whereas it was mostly cytosolic in c-Cbl ${ }^{+/+}$mice (Figure 8, B-D). Further analysis of number of intestinal cells positive for nuclear $\beta$ catenin and SOX9 was performed between ${\mathrm{c}-\mathrm{Cbl}^{+/+}}^{+1}$ and c$\mathrm{Cbl}^{+/-}$mice. Ten randomly selected bases of the crypts were examined in a blinded manner (M.B.). The cells positive with the nuclear $\beta$-catenin or SOX9 were counted and
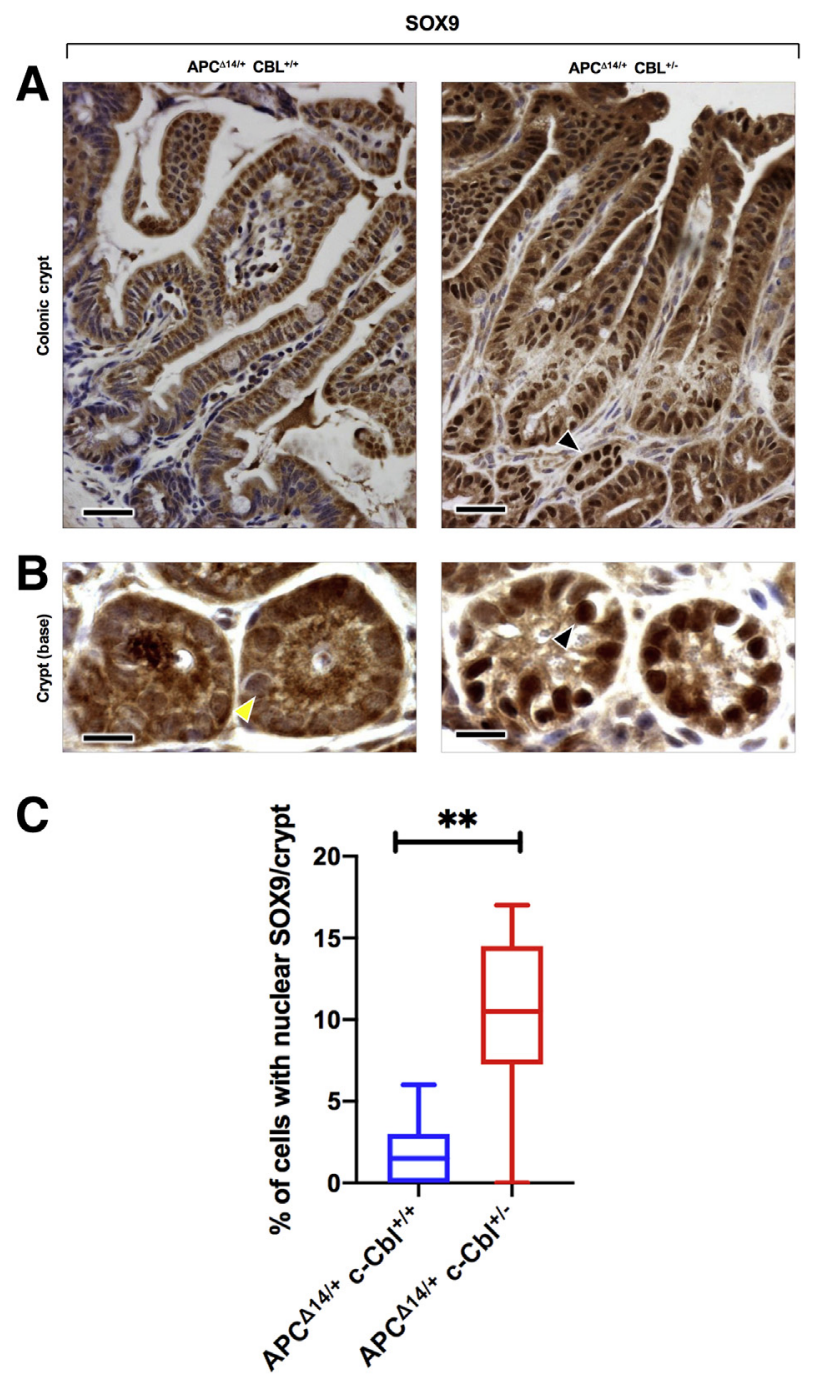

Figure 6 Increase in nuclear SOX9 in intestinal cells with reduced c-Cbl activity. A: Immunohistochemistry of SOX9-stained sections of colonic tissue from both the groups of mice. Slides were counterstained with hematoxylin. Representative images from $\mathrm{APC}^{\Delta 14 /+} \mathrm{c}_{-} \mathrm{Cbl}^{+/+}$and $\mathrm{APC}^{\Delta 14 /+} \mathrm{c}$ $\mathrm{Cbl}^{+/-}$mice are shown. B: Representative images of the base of the crypt from mice as described in A. C: Colonic epithelial cells at the base of crypts displaying nuclear SOX9 were counted and expressed as the percentage of total number of cells per crypt. Average of percentage cells positive for nuclear SOX9 from 10 randomly selected crypts from five mice from each group is shown. Yellow arrowheads indicate cells without nuclear SOX9; black arrowheads, cells with nuclear S0X9. Error bars indicate SD (C). ${ }^{*} P<0.01$ ( $t$-test). Scale bars: $25 \mu \mathrm{m}(\mathbf{A}) ; 10 \mu \mathrm{m}$ (B). Original magnification: $\times 100($ A $) ; \times 200(B)$.

normalized per crypt. A total of $2.5 \%+1.5 \%$ of intestinal cells/crypt of $\mathrm{Cbl}^{+/+}$mice showed nuclear $\beta$-catenin, whereas there was sixfold increase in cells bearing nuclear $\beta$-catenin in $\mathrm{Cbl}^{+/-}$mice $(24.9 \%+16.68 \%$ cell/crypt; $P<0.001)$. An approximately fivefold increase in nuclear SOX9 was noted in $\mathrm{Cbl}^{+/-}$mice compared with $\mathrm{Cbl}^{+/+}$ mice $\left(\mathrm{Cbl}^{+/-}\right.$mice versus $\mathrm{Cbl}^{+/+}$mice, $11.3 \%+13.5 \%$ versus $1.5 \%+2.0 \%$ of intestinal cells/crypt; $P=0.033$ ). Both these data suggest increase in Wnt target genes, nuclear $\beta$-catenin, and SOX9 (Figure 9). Despite these signs of 


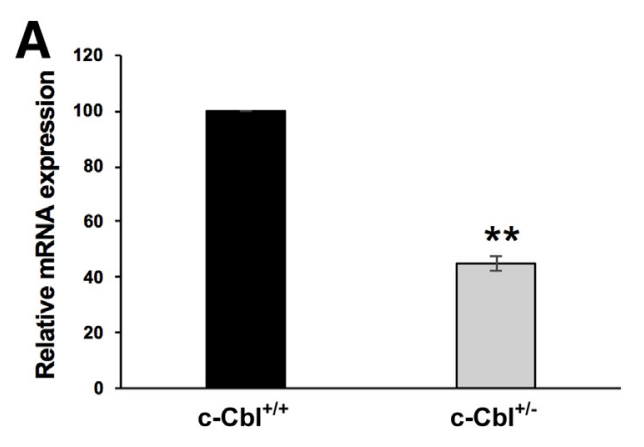

B
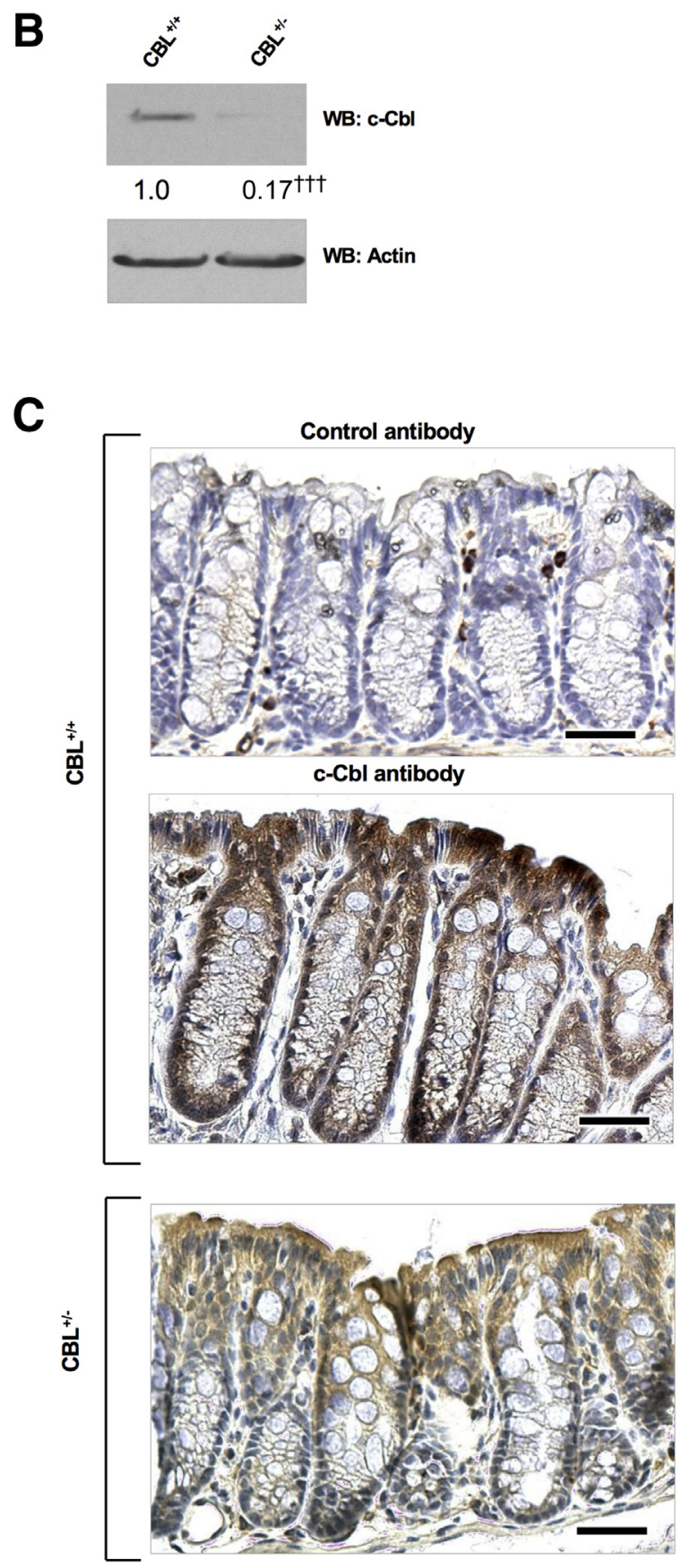

activated Wnt signaling, histopathologic analysis of the intestines of these mice showed no evidence of adenoma or other intestinal lesions. These results indicated that haploinsufficiency of c-Cbl alone is not sufficient to drive tumorigenesis and that $\mathrm{c}-\mathrm{Cbl}$ needs APC inactivation for it to allow progression of the lesion. ${ }^{35}$

\section{Discussion}

The current study demonstrates that the haploinsufficiency of c-Cbl on the background of $A P C$ mutation is sufficient to drive nuclear $\beta$-catenin and Wnt activity in the intestinal epithelium and results in increased frequency of atypical hyperplasia and adenocarcinoma development in mice. Interestingly, although there was no difference in the frequency of adenomas between the two groups, the results from this work indicated that loss of c-Cbl augmented the progression of lesions to adenocarcinoma. This notion was further supported by the fact that some of the lesions in the colon were noted earlier (12 to 16 weeks) in $\mathrm{APC}^{+/+} \mathrm{c}$ $\mathrm{Cbl}^{+/-}$mice. In addition, adenomas or other lesions were not observed in the intestines of $\mathrm{APC}^{+/+} \mathrm{c}_{-} \mathrm{Cbl}^{+/-}$mice followed up to 6 months. Although long-term changes in c$\mathrm{Cbl}^{+/-}$mice were not examined in this study, these observations suggest that $\mathrm{c}-\mathrm{Cbl}$ alone may not be sufficient to initiate CRC tumorigenesis. These results are consistent with the current understanding of the gatekeeper function of $A P C$ in initiating colon adenoma formation and support the multihit model of CRC pathogenesis. ${ }^{6,35}$ This work highlights a previously unrecognized role of $\mathrm{c}-\mathrm{Cbl}$ in solid organ tumorigenesis, whereas traditionally myeloproliferative disorders have remained the focus for c-Cbl biology. ${ }^{36}$

Sporadic colorectal cancer, which represents most human CRC, develops from normal colonic epithelium in an interdigitated set of well-defined histopathologic changes. The progression of CRC is characterized by a plethora of genetic and epigenetic alterations, ${ }^{35}$ and Wnt signaling is considered to play critical roles in several steps of CRC tumorigenesis. The association of reduced c-Cbl activity with an increased proportion of mice with adenocarcinomas may suggest that $\mathrm{c}-\mathrm{Cbl}$ contributes to the progression of

Figure $7 \quad \mathrm{c}-\mathrm{Cbl}^{+/-}$mice show reduced levels of $\mathrm{c}-\mathrm{Cbl}$ in other organs and in intestinal epithelial cells. A: RT-PCR was used to confirm reduction in CBL mRNA. Average of three independent experiment is shown. $t$-test was used. B: The kidneys were harvested and the lysates were probed for c-Cbl and actin, which served as a loading control. ImageJ software version 2.0.0-rc9 (NIH, Bethesda, MD; https://imagej.nih.gov/ij) was used to normalize the $\mathrm{c}-\mathrm{Cbl}$ band and is depicted below the $\mathrm{c}-\mathrm{Cbl}$ immunoblot. Representative immunoblot from three experiments is shown. C: Colonic tissue of mice was stained for $\mathrm{c}-\mathrm{Cbl}$ and counterstained with hematoxylin. Representative images from $25 \mathrm{APC}^{\Delta 14 /+} \mathrm{c}_{-} \mathrm{Cbl}^{+/+}$mice and $\mathrm{APC}^{\Delta 14 /+} \mathrm{c}^{-\mathrm{Cbl}^{+/-}}$mice are shown. Error bars indicate SEM (A). ${ }^{* *} P<0.01$ versus $\mathrm{C}-\mathrm{Cbl}^{+/+} ;{ }^{\dagger \dagger \dagger} P<0$. 001 versus $\mathrm{CBL}^{+/+}$. Scale bar $=25 \mu \mathrm{m}(\mathrm{C})$. Original magnification, $\times 100$ (C). WB, Western blot. 

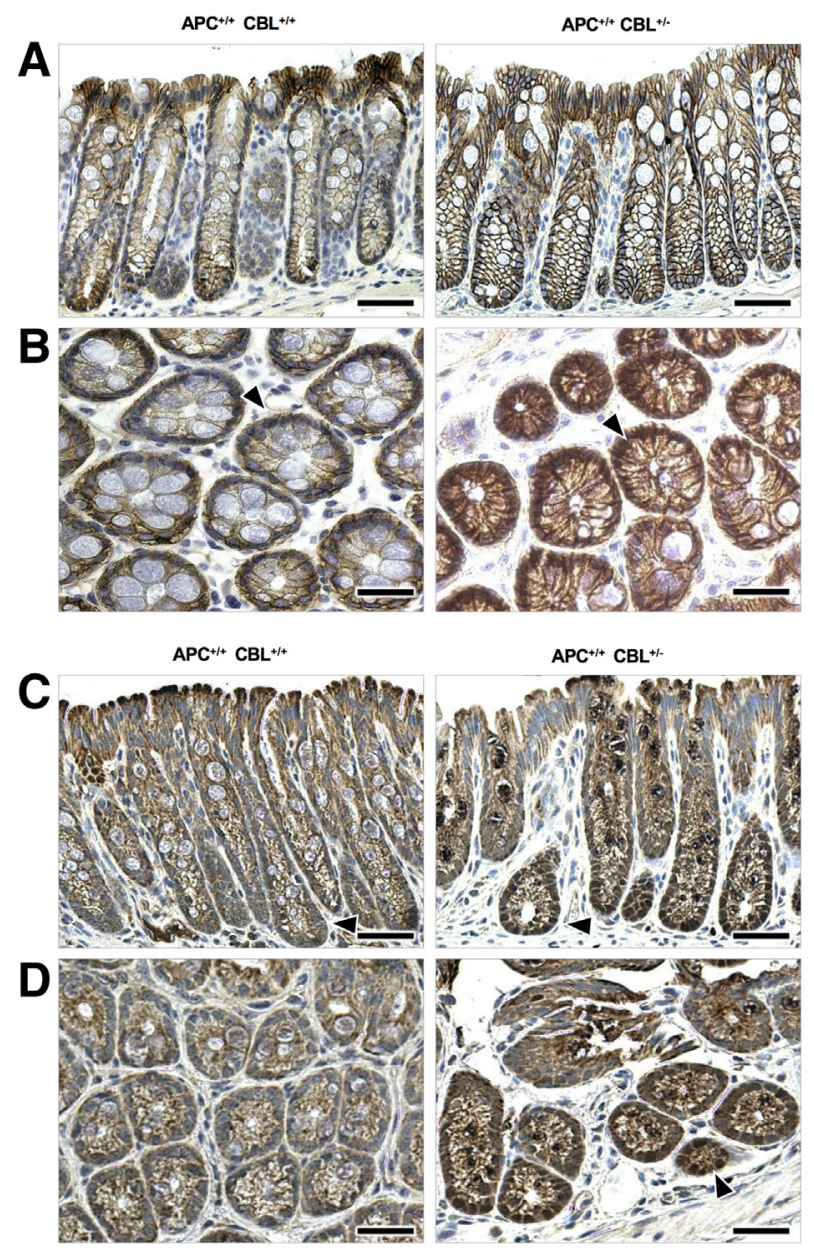

Figure $8 \quad \mathrm{c}_{-} \mathrm{Cbl}^{+/-}$mice show increased number of cells with nuclear $\beta$ catenin. A: Immunohistochemistry of $\beta$-catenin-stained sections of colonic tissue from both the groups of mice. Slides were counterstained with hematoxylin. Representative images from $\mathrm{APC}^{+/+} \mathrm{C}_{-} \mathrm{Cbl}^{+/+}$and $\mathrm{APC}^{+/+}$

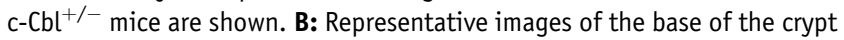
from mice, as described in A. Arrowheads indicate cells expressing nuclear $\beta$-catenin. C: Immunohistochemistry of SOX9-stained sections of colonic tissue from both the groups of mice. Slides were counterstained with he-

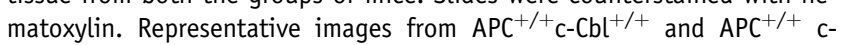
$\mathrm{Cbl}^{+/-}$mice are shown. Arrowheads indicate negatively stained nuclei in

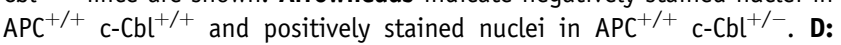
Representative images of the base of the crypt stained for SOX9 from mice. Arrowhead indicates cells expressing nuclear $\beta$-catenin. Scale bars: $25 \mu \mathrm{m}$ $(\mathbf{A}$ and $\mathbf{C}) ; 10 \mu \mathrm{m}(\mathbf{B}$ and $\mathbf{D})$. Original magnification: $\times 100(\mathbf{A}$ and $\mathbf{C}) ; \times 200$ (B and D).

adenoma to adenocarcinomas. This observation prompted the question as to why reduction in c-Cbl activity was not associated with an increase in the adenomas, given the central role of Wnt signaling in the conversion of normal epithelial cells to adenoma. It is plausible that the reduction in c-Cbl may be compensated by other mechanisms or other ubiquitin E3 ligases. E3 ligases of $\beta$-catenin, such as $\beta$-TrCP and Jade- 1 , bind and degrade wild-type phosphorylated $\beta$-catenin, ${ }^{7,9}$ not hypophosphorylated $\beta$-catenin, a species dominant in the presence of inactivated $A P C$. However, further studies are needed to elucidate potential underlying mechanisms that compensate for the loss of
c-Cbl in early phase of CRC tumorigenesis but not in the late phase.

One potential mechanism by which loss of c-Cbl could contribute to CRC tumorigenesis is regulation of cancer stem cells as loss of c-Cbl increased SOX9 expression, which is a marker for stem cells in intestine. Recent work has implicated cancer stem cells as the initiators of CRC, and Wnt signaling is implicated in generating the cancer stem cells from normal stem cells or noncancer stem cells at the base of the crypt. ${ }^{37}$ Cancer stem cells are responsible for conversion of adenoma to adenocarcinoma and then subsequently invade the local milieu to metastasize in blood. This particular process is orchestrated by Wnt signaling by maintaining the stem cells in a dormant state to ensure their survival during this process. Up-regulation of Wnt activity in these metastatic cells leads them to homing in distant organs and allows for the initiation of the metastatic foci. ${ }^{37}$ Whether c-Cbl activity is involved in these processes requires further investigation.

Another important aspect of $\mathrm{c}-\mathrm{Cbl}$ in $\mathrm{CRC}$ is pattern of its expression. A colonic crypt shows a gradient in the expression of c-Cbl along the crypt-villus axis, with the lowest expression at the base of the crypt and the highest expression at the apices of the crypts, suggesting a potentially important role for $\mathrm{c}-\mathrm{Cbl}$ in a distinct population of intestinal epithelial cells. The apical part of the crypt usually harbors differentiated cells and is not expected to have cells with nuclear $\beta$-catenin. There can be various explanations for the mechanisms that lead to the $\mathrm{c}-\mathrm{Cbl}$ gradient along the crypt-villus axis. It is likely that the gradient in the levels of $\mathrm{c}-\mathrm{Cbl}$ is maintained by the epigenetic regulation of $C B L$ or post-translational modification of $\mathrm{c}-\mathrm{Cbl}$ protein. $\mathrm{c}-\mathrm{Cbl}$ undergoes several post-translational modifications, such as phosphorylation at the exposed tyrosine residues. It is an E3
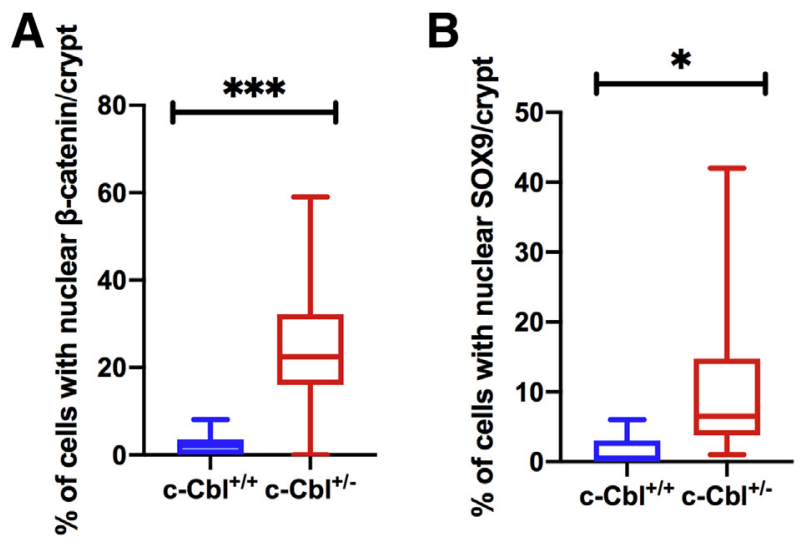

Figure 9 Increased number of cells with nuclear $\beta$-catenin and S0X9 in $\mathrm{c}-\mathrm{Cbl}^{+/-}$mice. A and B: Colonic epithelial cells at the base of crypts, displaying nuclear $\beta$-catenin or SOX9, were counted and expressed as the percentage of total number of cells per crypt. Averages of percentage cells positive for nuclear $\beta$-catenin or S0X9 from 10 randomly selected crypts from five mice from each group are shown. Error bars indicate SD (A and $\mathbf{B})$. ${ }^{\star} P<0.05,{ }^{* *} P<0.001$ ( $t$-test). 
ubiquitin ligase, which are known to undergo autoubiquitination or deubiquitination. ${ }^{38}$

c-Cbl has several targets, including receptor tyrosine kinases, such as c-Met, and nonreceptor tyrosine kinases, such as c-Src, that are up-regulated in CRC. ${ }^{12}$ Although c-Cbl directly interacts with $\beta$-catenin and regulates Wnt signaling independent of these other pathways, the contribution of other mitogens regulated by $\mathrm{c}-\mathrm{Cbl}$ cannot be ruled out.

$\mathrm{c}-\mathrm{Cbl}$ has a translational potential in CRC. ${ }^{39}$ In combination with previous data, this work supports the notion that c-Cbl down-regulates two key components of CRCepithelial tumorigenesis and tumor-induced angiogenesis. $^{11,40,41}$ In CRC cells, c-Cbl suppresses the growth of colon cancer cells by down-regulating Wnt signaling and suppressing nuclear $\beta$-catenin. ${ }^{10}$ In fact, the expression of $\mathrm{c}$ $\mathrm{Cbl}$ in colorectal tumors inversely correlated with the overall survival of human stage IV CRC patients. ${ }^{34} \mathrm{c}-\mathrm{Cbl}$ also suppresses other mitogenic proteins, such as c-MET, platelet-derived growth factor, and fibroblast growth factor, that are up-regulated in colorectal and other cancers. ${ }^{12} \mathrm{At}$ the same time, $\mathrm{c}-\mathrm{Cbl}$ inhibits tumor-induced angiogenesis by targeting $\mathrm{Wnt} / \beta$-catenin pathway and phospholipase C $\gamma$-1-vascular endothelial growth factor receptor 2 signaling, ${ }^{40,42-44}$ Angiopoietin (1/2)-Tie2 axis, and other tyrosine kinases. ${ }^{40,41}$ The crystal structure of c-Cbl has provided an interesting hypothesis-generating insight into conversion of autoinhibition conformation of $\mathrm{c}-\mathrm{Cbl}$ to an active conformation. The phosphorylation of specific tyrosine residue(s) in this process can be perturbed to leverage therapeutic value of $\mathrm{c}-\mathrm{Cbl}{ }^{45}$ Together with previously published work, the current study demonstrates c-Cbl as a Wnt inhibitor in the colonic epithelium and a suppressor of CRC tumorigenesis. ${ }^{8,10,11}$ Given the versatile role of $\mathrm{c}-\mathrm{Cbl}$ in the biology of CRC cancer, ${ }^{39}$ investigations to examine c$\mathrm{Cbl}$ as a marker for overall prognosis and other aspects of $\mathrm{CRC}$, such as responsiveness to targeted therapeutic agents, will pave the path forward for its translational application.

\section{Acknowledgments}

We thank Michael Kirber, the imaging core facilities of the Department of Medicine (Boston Medical Center and Boston University School of Medicine), and the Department of Pathology (Boston Medical Center and Boston University School of Medicine) for assistance; Joseph Tashjian (Boston University School of Medicine) for technical assistance; Dr. Jeffrey Chiang (National Cancer Institute) for kindly

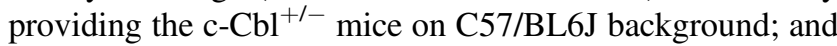
Dr. Daniel Rosenberg (University of Connecticut Health Center) for kindly providing the $\mathrm{APC}^{\Delta 14 /+}$ mice.

\section{Supplemental Data}

Supplemental material for this article can be found at http://doi.org/10.1016/j.ajpath.2019.10.024.

\section{References}

1. Miller KD, Siegel RL, Lin CC, Mariotto AB, Kramer JL, Rowland JH, Stein KD, Alteri R, Jemal A: Cancer treatment and survivorship statistics, 2016. CA Cancer J Clin 2016, 66: 271-289

2. Arnold M, Sierra MS, Laversanne M, Soerjomataram I, Jemal A, Bray F: Global patterns and trends in colorectal cancer incidence and mortality. Gut 2017, 66:683-691

3. Vogelstein B, Fearon ER, Hamilton SR, Kern SE, Preisinger AC, Leppert M, Nakamura Y, White R, Smits AM, Bos JL: Genetic alterations during colorectal-tumor development. N Engl J Med 1988, 319:525-532

4. Lynch HT, de la Chapelle A: Hereditary colorectal cancer. N Engl J Med 2003, 348:919-932

5. Zhan T, Rindtorff N, Boutros M: Wnt signaling in cancer. Oncogene 2017, 36:1461-1473

6. Markowitz SD, Bertagnolli MM: Molecular origins of cancer: molecular basis of colorectal cancer. N Engl J Med 2009, 361: $2449-2460$

7. Chitalia VC, Foy RL, Bachschmid MM, Zeng L, Panchenko MV, Zhou MI, Bharti A, Seldin DC, Lecker SH, Dominguez I, Cohen HT: Jade-1 inhibits Wnt signalling by ubiquitylating beta-catenin and mediates Wnt pathway inhibition by pVHL. Nat Cell Biol 2008, 10: $1208-1216$

8. Chitalia V, Shivanna S, Martorell J, Meyer R, Edelman E, Rahimi N: c-Cbl, a ubiquitin E3 ligase that targets active beta-catenin: a novel layer of Wnt signaling regulation. J Biol Chem 2013, 288: 23505-23517

9. Latres E, Chiaur DS, Pagano M: The human F box protein beta-Trep associates with the Cul1/Skp1 complex and regulates the stability of beta-catenin. Oncogene 1999, 18:849-854

10. Shashar M, Siwak J, Tapan U, Lee SY, Meyer RD, Parrack P, Tan J, Khatami F, Francis J, Zhao Q, Hartshorn K, Kolachalama VB, Rahimi N, Chitalia V: c-Cbl mediates the degradation of tumorigenic nuclear beta-catenin contributing to the heterogeneity in Wnt activity in colorectal tumors. Oncotarget 2016, 7:71136-71150

11. Shivanna S, Harrold I, Shashar M, Meyer R, Kiang C, Francis J, Zhao Q, Feng H, Edelman ER, Rahimi N, Chitalia VC: The c-Cbl ubiquitin ligase regulates nuclear beta-catenin and angiogenesis by its tyrosine phosphorylation mediated through the Wnt signaling pathway. J Biol Chem 2015, 290:12537-12546

12. Schmidt MH, Dikic I: The Cbl interactome and its functions. Nat Rev Mol Cell Biol 2005, 6:907-918

13. McCart AE, Vickaryous NK, Silver A: Apc mice: models, modifiers and mutants. Pathol Res Pract 2008, 204:479-490

14. Colnot S, Niwa-Kawakita M, Hamard G, Godard C, Le Plenier S, Houbron C, Romagnolo B, Berrebi D, Giovannini M, Perret C: Colorectal cancers in a new mouse model of familial adenomatous polyposis: influence of genetic and environmental modifiers. Lab Invest 2004, 84:1619-1630

15. El Chami N, Ikhlef F, Kaszas K, Yakoub S, Tabone E, Siddeek B, Cunha S, Beaudoin C, Morel L, Benahmed M, Regnier DC: Androgen-dependent apoptosis in male germ cells is regulated through the proto-oncoprotein Cbl. J Cell Biol 2005, 171:651-661

16. Naramura M, Kole HK, Hu RJ, Gu H: Altered thymic positive selection and intracellular signals in Cbl-deficient mice. Proc Natl Acad Sci U S A 1998, 95:15547-15552

17. Nolte T, Brander-Weber P, Dangler C, Deschl U, Elwell MR, Greaves P, Hailey R, Leach MW, Pandiri AR, Rogers A, Shackelford CC, Spencer A, Tanaka T, Ward JM: Nonproliferative and proliferative lesions of the gastrointestinal tract, pancreas and salivary glands of the rat and mouse. J Toxicol Pathol 2016, 29: $1 \mathrm{~S}-125 \mathrm{~S}$

18. Humphries A, Wright NA: Colonic crypt organization and tumorigenesis. Nat Rev Cancer 2008, 8:415-424 
19. Barker N, van Es JH, Kuipers J, Kujala P, van den Born M, Cozijnsen M, Haegebarth A, Korving J, Begthel H, Peters PJ, Clevers $\mathrm{H}$ : Identification of stem cells in small intestine and colon by marker gene Lgr5. Nature 2007, 449:1003-1007

20. van de Wetering M, Sancho E, Verweij C, de Lau W, Oving I, Hurlstone A, van der Horn K, Batlle E, Coudreuse D, Haramis AP, Tjon-Pon-Fong M, Moerer P, van den Born M, Soete G, Pals S, Eilers M, Medema R, Clevers H: The beta-catenin/TCF-4 complex imposes a crypt progenitor phenotype on colorectal cancer cells. Cell 2002, 111:241-250

21. Zeineldin M, Cunningham J, McGuinness W, Alltizer P, Cowley B, Blanchat B, Xu W, Pinson D, Neufeld KL: A knock-in mouse model reveals roles for nuclear Apc in cell proliferation, Wnt signal inhibition and tumor suppression. Oncogene 2012, 31:2423-2437

22. Sansom OJ, Reed KR, Hayes AJ, Ireland $\mathrm{H}$, Brinkmann $\mathrm{H}$, Newton IP, Batlle E, Simon-Assmann P, Clevers H, Nathke IS, Clarke AR, Winton DJ: Loss of Apc in vivo immediately perturbs Wnt signaling, differentiation, and migration. Genes Dev 2004, 18 : $1385-1390$

23. Qian Z, Chen L, Fernald AA, Williams BO, Le Beau MM: A critical role for Apc in hematopoietic stem and progenitor cell survival. J Exp Med 2008, 205:2163-2175

24. Mushinski JF, Goodnight J, Rudikoff E, Morse HC 3rd, Langdon WY: Expression of c-cbl proto-oncogene is modulated during differentiation but not during induction of proliferation. Oncogene 1994, 9:2489-2497

25. Menoret A, Drew DA, Miyamoto S, Nakanishi M, Vella AT, Rosenberg DW: Differential proteomics identifies PDIA3 as a novel chemoprevention target in human colon cancer cells. Mol Carcinog 2014, 53 Suppl 1:E11-E22

26. Mo A, Jackson S, Varma K, Carpino A, Giardina C, Devers TJ, Rosenberg DW: Distinct transcriptional changes and epithelialstromal interactions are altered in early-stage colon cancer development. Mol Cancer Res 2016, 14:795-804

27. Gregorieff A, Clevers H: Wnt signaling in the intestinal epithelium: from endoderm to cancer. Genes Dev 2005, 19:877-890

28. Jho EH, Zhang T, Domon C, Joo CK, Freund JN, Costantini F: Wnt/beta-catenin/Tcf signaling induces the transcription of Axin2, a negative regulator of the signaling pathway. Mol Cell Biol 2002, 22: $1172-1183$

29. Cong F, Varmus H: Nuclear-cytoplasmic shuttling of Axin regulates subcellular localization of beta-catenin. Proc Natl Acad Sci U S A 2004, 101:2882-2887

30. Rennoll SA, Konsavage WM Jr, Yochum GS: Nuclear AXIN2 represses MYC gene expression. Biochem Biophys Res Commun 2014, 443:217-222

31. Wu ZQ, Brabletz T, Fearon E, Willis AL, Hu CY, Li XY, Weiss SJ: Canonical Wnt suppressor, Axin2, promotes colon carcinoma oncogenic activity. Proc Natl Acad Sci U S A 2012, 109: $11312-11317$

32. Blache P, van de Wetering M, Duluc I, Domon C, Berta P, Freund JN, Clevers H, Jay P: SOX9 is an intestine crypt transcription factor, is regulated by the Wnt pathway, and represses the CDX2 and MUC2 genes. J Cell Biol 2004, 166:37-47

33. Bastide P, Darido C, Pannequin J, Kist R, Robine S, MartyDouble C, Bibeau F, Scherer G, Joubert D, Hollande F, Blache P, Jay P: Sox9 regulates cell proliferation and is required for Paneth cell differentiation in the intestinal epithelium. J Cell Biol 2007, 178:635-648

34. Kumaradevan S, Lee SY, Richards S, Lyle C, Zhao Q, Tapan U, Jiangliu Y, Ghumman S, Walker J, Belghasem M, Arinze N, Kuhnen A, Weinberg J, Francis J, Hartshorn K, Kolachalama VB, Cifuentes D, Rahimi N, Chitalia VC: c-Cbl expression correlates with human colorectal cancer survival and its Wnt/beta-catenin suppressor function is regulated by Tyr371 phosphorylation. Am J Pathol 2018, 188:1921-1933

35. Fearon ER, Vogelstein B: A genetic model for colorectal tumorigenesis. Cell 1990, 61:759-767

36. Niemeyer CM, Kang MW, Shin DH, Furlan I, Erlacher M, Bunin NJ, Bunda S, Finklestein JZ, Sakamoto KM, Gorr TA, Mehta P, Schmid I, Kropshofer G, Corbacioglu S, Lang PJ, Klein C, Schlegel PG, Heinzmann A, Schneider M, Stary J, van den HeuvelEibrink MM, Hasle H, Locatelli F, Sakai D, Archambeault S, Chen L, Russell RC, Sybingco SS, Ohh M, Braun BS, Flotho C, Loh ML: Germline CBL mutations cause developmental abnormalities and predispose to juvenile myelomonocytic leukemia. Nat Genet 2010, 42:794-800

37. Kim JH, Park SY, Jun Y, Kim JY, Nam JS: Roles of Wnt target genes in the journey of cancer stem cells. Int J Mol Sci 2017, 18:1604

38. de Bie P, Ciechanover A: Ubiquitination of E3 ligases: self-regulation of the ubiquitin system via proteolytic and non-proteolytic mechanisms. Cell Death Differ 2011, 18:1393-1402

39. Lyle CL, Belghasem M, Chitalia VC: c-Cbl: an important regulator and a target in angiogenesis and tumorigenesis. Cells 2019, 8:498

40. Meyer RD, Husain D, Rahimi N: c-Cbl inhibits angiogenesis and tumor growth by suppressing activation of PLCgamma1. Oncogene 2011, 30:2198-2206

41. Rahimi N: The ubiquitin-proteasome system meets angiogenesis. Mol Cancer Ther 2012, 11:538-548

42. Husain D, Meyer RD, Mehta M, Pfeifer WM, Chou E, Navruzbekov G, Ahmed E, Rahimi N: Role of c-Cbl-dependent regulation of phospholipase Cgammal activation in experimental choroidal neovascularization. Invest Ophthalmol Vis Sci 2010, 51: 6803-6809

43. Prenen H, Smeets D, Mazzone M, Lambrechts D, Sagaert X, Sciot R, Debiec-Rychter M: Phospholipase C gamma 1 (PLCG1) R707Q mutation is counterselected under targeted therapy in a patient with hepatic angiosarcoma. Oncotarget 2015, 6:36418-36425

44. Wang Y, Wu J, Wang Z: Akt binds to and phosphorylates phospholipase C-gammal in response to epidermal growth factor. Mol Biol Cell 2006, 17:2267-2277

45. Dou H, Buetow L, Hock A, Sibbet GJ, Vousden KH, Huang DT: Structural basis for autoinhibition and phosphorylation-dependent activation of c-Cbl. Nat Struct Mol Biol 2012, 19:184-192 